\title{
Rever o passado para estigmatizar um presente incômodo: Montano e outros "heresiarcas" do século II no olhar de Euclides da Cunha sobre Antonio Conselheiro"
}

\author{
Revisitar el passado para estigmatizar un presente molesto: Montano y otros herejes del \\ siglo II en la mirada de Euclides da Cunha sobre Antonio Conselheiro
}

\section{Pedro Lima Vasconcellos}

Resumo: O artigo trata de como Euclides da Cunha, em Os sertões, aborda líderes cristãos do século II, tomados como heréticos, em vistas a estigmatizar a figura de Antonio Conselheiro. Particularmente o teor milenarista do anúncio de Montano, aplicado sem mais como chave interpretativa da pregação do Conselheiro, serve para afirmar a inviabilidade histórica do que o Belo Monte (mais conhecido como Canudos) representava para os homens e mulheres do sertão que nele apostaram suas vidas. Destaca-se como o equívoco do autor se deve também ao preconceito com a religião e com o lugar central que ela ocupava no projeto conselheirista.

Palavras-chave: Antonio Conselheiro, Euclides da Cunha, Montano, heresia, milenarismo, Belo Monte.

Resumen: El artículo trata de como Euclides da Cunha, en Los sertones, aborda liderazgos cristianos del siglo II, tomados como heréticos, en vistas a estigmatizar la figura de Antonio

\footnotetext{
"Retoma-se comunicação apresentada no "Simpósio Internacional Os sertões: permanência e rasuras", organizado pela Universidade Federal da Bahia em dezembro de 2002. O argumento aparece aqui ampliado para além do que foi sua exposição originária.

Doutor em Antropologia pela PUC-SP (2004) e livre-docente em Ciências da Religião pela mesma Universidade (2009). Atualmente é Professor adjunto da Universidade Federal de Alagoas e efetivo no curso de Pós-Graduação em História da UFAL. Pesquisador do Laboratório Interdisciplinar de Estudo das Religiões (LIER-UFAL).
}

Recebido em 5 de setembro de 2016 e aprovado para publicação em 25 de setembro de 2016 
Conselheiro (Consejero). En especial el contenido milenarista del anuncio de Montano, aplicado sin más como clave interpretativa de la predicación del Conselheiro sirve para afirmar la inviabilidad histórica de lo que el Belo Monte (más conocido como Canudos) representaba para los hombres y mujeres del sertón que en él han apostado sus vidas. Se destaca como el equívoco del autor tiene que ver también con su prejuicio con la religión y el lugar central que ella ocupaba en el proyecto "conselheirista".

Palabras-clave: Antonio Conselheiro, Euclides da Cunha, Montano, herejía, milenarismo, Belo Monte.

\section{Introdução}

Não terá passado despercebida, a quem percorra as páginas em que Euclides da Cunha delineia o perfil de Antônio Conselheiro, encontrar este último caracterizado como "um heresiarca do século II em plena Idade Moderna" (CUNHA, 200I, p. 278). Ninguém discute a força retórica dessa expressão, que, aliás, se soma a tantas outras que fazem de Os sertões uma obra de eloquência admirável. Mas seguramente se prestou pouca atenção às razões que levaram o escritor fluminense a recuar aos inícios do cristianismo e aí localizar o Conselheiro, lamentando que um personagem com esta configuração aparecesse tanto tempo depois. Seria desinteresse da crítica ou suspeita de que, sendo o autor agnóstico, seus enunciados a respeito seriam irrelevantes? Se a razão fosse esta última, estariam sendo desconsideradas as não poucas observações que dão conta de um Euclides "supersticioso e preocupado com o problema religioso, embora se classificasse 'livre-pensador"' (ANDRADE, 2002, p. I84). Resta a primeira alternativa, e ela justifica a proposição que neste artigo tratarei de desenvolver.

Impõe-se um olhar sobre as intenções de Euclides ao estigmatizar Antonio Conselheiro

como herege (além de louco), para que se compreendam as estratégias utilizadas na configuração de Os sertões, em que pretende tomar a defesa da gente de Belo Monte ao mesmo tempo em que afirma a inviabilidade do arraial conselheirista. A obra de Ernest Renan, particularmente o volume Marc-Aurèle et la fin du monde antique, que encerra sua impactante Histoire des origines du christianisme (surgida entre I863 e I882), teve aí lugar central, por ter descortinado a Euclides um universo sugestivo. Sua leitura forma, com as teorias das escolas 
antropológica italiana e da psicologia das multidões, o arcabouço teórico da análise sobre a religiosidade do Conselheiro e de sua gente que é proposta em Os sertões (OTTEN, I990, p. 5I).

É a essa questão muito específica que me dedicarei. A suspeita é de que o engenheiroescritor de Os sertões tenha supervalorizado alguns documentos que encontrou entre os escombros do arraial praticamente destruído e os tenha inserido, não sem riscos, no interior do quadro que Renan lhe desenhara a respeito dos inícios cristãos, afinal dando a eles interpretação mais que discutível, embora amplamente acolhida na fortuna crítica posterior. Recolherei os dados que o próprio Euclides toma emprestado ao pensador francês, dando particular atenção à forma como Montano e o movimento que leva seu nome aparecem aí, dada a proximidade que teria com o Conselheiro e sua gente. Com isso pretendo identificar razões que levaram Euclides a se embrenhar em universo assim distante na busca de compreender outro mundo até então desconhecido: o sertão.

\section{Uma legião de anônimos e ignotos extravagantes}

No fatídico e fulcral capítulo IV de "O homem", quando finalmente Euclides faz a apresentação de Antonio Vicente Mendes Maciel, “o falso apóstolo”, não demora muito e somos remetidos "aos primeiros dias da Igreja, quando o gnosticismo universal se erigia como transição obrigatória entre o paganismo e o cristianismo” (CUNHA, 200I, p. 254). Esse deslocamento até um momento longínquo da história se justifica: "um antropologista encontrá-lo-ia [o Conselheiro] normal, marcando logicamente certo nível da mentalidade humana, recuando no tempo, fixando uma fase remota da evolução" (CUNHA, 200I, p. 254). Assim, é pela perspectiva evolucionista, que, aliás, marca todo o livro, que leitor e leitora são conduzidos até as origens do cristianismo. Mas veremos que não é só isso.

Euclides cita, um a um, movimentos surgidos no cristianismo dos primeiros séculos, com os quais tomou contato justamente pela leitura do volume já citado de Renan. Entre eles, caberiam muito bem Antônio Conselheiro e sua gente. Quanto aos "adamitas infames" (CUNHA, 200I, p. 255), eram discípulos de um tal Pródico e, nos dizeres do francês,

pretendiam renovar os dias do paraíso terrestre por meio de práticas muito afastadas da inocência primitiva. Sua Igreja se chamava o Paraíso; eles a 
aqueciam e se mantinham nus... [Eles] negavam o valor das leis estabelecidas, que qualificavam como regras arbitrárias (RENAN, I929, p. I25-I26).

Os ofiólatras eram "pagãos adoradores da serpente, a quem conveio um dia chamar-se cristãos" (RENAN, I929, p. 132). Já os maniqueus, "bifrontes entre o ideal cristão emergente e o budismo antigo" (CUNHA, 200I, p. 255), estavam de antemão condenados ao fracasso na sua tentativa de conciliar a cosmovisão panteísta oriental com "o quadro de uma religião semítica" (RENAN, 1929, p. 136). Por sua vez, "os discípulos de Markos" seguiam alguém, oriundo da escola do então famoso mestre gnóstico Basílides, que propunha "fórmulas sobre a tétrade, que pretendia terem sido reveladas a ele por uma mulher celeste". Praticou a magia, "inventou sacramentos particulares, ritos, unções" e desenvolveu "artes reprováveis para seduzir as mulheres" (RENAN, 1929, p. 127). Finalmente os "encratitas abstinentes" (CUNHA, 200I, p. 255) repudiavam o casamento (e, por consequência, as relações sexuais), o vinho e a carne, e se serviam apenas de água nos rituais (RENAN, 1929, p. I66-I67).

A lista é um tanto extensa, e não teria razão de constar na exposição de Euclides não fosse a síntese final, que dissipa qualquer dúvida: "relendo as páginas memoráveis em que Renan faz ressurgir, pelo galvanismo do seu belo estilo, os adoidados chefes de seita dos primeiros séculos, nota-se [em Antônio Conselheiro] a revivescência integral de suas aberrações extintas" (CUNHA, 200I, p. 275). O atavismo do beato de Belo Monte se explicaria justamente quando se consideram a ação e os ensinamentos desses desconhecidos, mas aloucados e marginais líderes do cristianismo do século II.

Mas há uma corrente a mais. O montanismo, que Euclides cita antes dos que acima foram apresentados, não é apenas um exemplo de insânia. $O$ autor descobre nele características específicas que tornam esclarecedora a aproximação com o movimento liderado pelo Conselheiro. Para Renan, o montanismo teria surgido por conta da demora da vinda de Cristo no dia final e pelo relaxamento vivido pela Igreja em função desse atraso:

cada vez era menor o contraste entre a Igreja e o mundo. Era inevitável que os rigoristas julgassem que se estava caindo no atoleiro da mais perigosa mundanidade e que surgisse um grupo de pietistas para combater o tédio geral, continuar os dons sobrenaturais da Igreja apostólica, e preparar a humanidade, por um redobramento de austeridades, para as provações dos últimos dias (RENAN, I929, p. 207-208). 
Esse seria o lugar ocupado, em algum momento do reinado de Marco Aurélio, imperador romano (I6I-I80), pelo montanismo:

Espíritos simples e exaltados imaginavam ser chamados a renovar os
prodígios da inspiração individual, fora das cadeias já pesadas da Igreja e do
episcopado. Uma doutrina há muito tempo espalhada na Ásia Menor, a de um
Paráclito que deveria vir completar a obra de Jesus, ou melhor, retomar o
ensinamento de Jesus, restabelecê-lo em sua verdade, purificá-lo das
adulterações que os apóstolos e os bispos nela haviam introduzido, tal
doutrina, digo eu, abria a porta a todas as inovações (RENAN, I929, p. 2Io).

A forma específica a essas novidades foi dada por um tal Montano, da vila de Ardabav, na Mísia, nos confins da Frígia (região interiorana do que hoje é a Turquia): "sem dúvida a imitação dos profetas judeus e dos que a lei nova havia produzido, no começo da idade apostólica, foi o elemento principal deste renascimento do profetismo” (RENAN, I929, p. 2II). E isso à margem das decisões episcopais: "era um profetismo totalmente popular que surgia sem a permissão do clero, e queria governar a Igreja fora da hierarquia" (RENAN, I929, p. 2I3). Desenvolvido também por Priscila e Maximila, este movimento teve enorme repercussão, conquistando para suas fileiras o célebre apologista Tertuliano. O rigorismo exigido de seus membros, a ânsia em recuperar o ardor dos inícios cristãos e a exortação insistente ao martírio fizeram do montanismo uma proclamação de enorme apelo no fim do século II e início do III.

Euclides não tem dúvidas quanto a ver no Conselheiro um novo Montano. O líder de Belo Monte "é um dissidente do molde exato de Themison. Insurge-se contra a Igreja romana, e vibra-lhe objurgatórias, estadeando o mesmo argumento que aquele: ela perdeu a sua glória e obedece a Satanás” (CUNHA, 200I, p. 275). Com efeito, de acordo com Renan, este personagem obscuro, um dos líderes da seita frígia, "declarava que a Igreja católica tinha perdido toda a sua glória e obedecia a Satanás" (RENAN, I929, p. 222). Cá e lá as reprimendas ao "demônio dos cabelos": se nos escritos montanistas, garante-nos Renan, aparecem constantemente "proibições do luxo feminino e, sobretudo, contra o artifício dos penteados" (RENAN, 1929, p. 243-244), no Belo Monte do Conselheiro eram punidas "as vaidosas com dilaceradores pentes de espinho" (CUNHA, 200I, p. 276). Que a beleza fosse "a face sedutora de Satã” (CUNHA, 200I, p. 276) Renan (I929, p. 553) já dizia ser convicção montanista. Na verdade, 
o ascetismo supostamente vivido em Belo Monte denunciaria a recriação do montanismo em terras sertanejas: "que os fiéis abandonassem todos os haveres, tudo quanto os maculasse com um leve traço da vaidade" (CUNHA, 200I, p. 276).

Mais adiante Euclides deixa ainda mais claro o vínculo que estabelece entre Montano e o Conselheiro: o frígio, mais que um indivíduo, é um paradigma:

Ademais esse voltar-se à idade de ouro dos apóstolos e sibilistas, revivendo vetustas ilusões, não é uma novidade. É o permanente refluxo do cristianismo para seu berço judaico. Montano reproduz-se em toda a história, mais ou menos alterado consoante o caráter dos povos, mas delatando, na mesma rebeldia contra a hierarquia eclesiástica, na mesma exploração do sobrenatural, e no mesmo ansiar pelos céus, a feição primitivamente sonhadora da velha religião, antes que a deformassem os sofistas canonizados dos concílios.

A exemplo de seus comparsas do passado, Antônio Conselheiro era um pietista ansiando pelo Reino de Deus, prometido, delongado sempre e ao cabo de todo esquecido pela Igreja ortodoxa do século II (CUNHA, 200I, p. 278279). ${ }^{\mathrm{I}}$

E não apenas se encontram no Conselheiro traços anteriormente verificados em Montano; Euclides considera possível supor no antigo heresiarca aquilo de que tinha certeza em relação ao líder sertanejo: "O frígio pregava-a [a moral, 'a castidade exagerada ao máximo horror pela mulher'], talvez como o cearense, pelos ressaibos remanentes das desditas conjugais" (CUNHA, 200I, p. 276).

\footnotetext{
${ }^{\mathrm{I}}$ Levar-nos-ia muito longe a discussão sobre o que seria, para Euclides, esse permanente "refluxo" (por parte dos hereges cristãos mencionados, ao "berço judaico" do cristianismo. Apenas se note que em Antonio Conselheiro se também se manifestaria, "uma forma superior de judaísmo" (CUNHA, 200I, p.279), justamente pelo milenarismo - do qual já se vai tratar - que, segundo o autor, caracterizaria a pregação do líder sertanejo. E se fique com a observação seguinte, formulada de modo um tanto tosco, mas que aponta claramente a questão: "os cristãos chamam 'judaizar' e 'judaísmo' a crença, que a Igreja chama de 'carnal', de que o Reino de Deus é deste mundo e não de outro" (CHAUÍ, 200o, p. 78). Aquilo que no judaísmo seria mostraria como uma "forma superior", soaria apenas como uma aproximação ao "catolicismo mal compreendido" (CUNHA, 200I, p.279).
} 


\section{A invenção euclidiana}

Mas esses pontos de contato são acessórios, na análise euclidiana. Mais importantes são as concepções de fundo, que definitivamente permitem pensar o sertanejo a partir do frígio:

Esta identidade [entre Montano e Conselheiro] avulta, mais frisante, quando se comparam com as do passado as concepções absurdas do esmaniado apóstolo sertanejo. Como os montanistas, ele surgia no epílogo da Terra... O mesmo milenarismo extravagante, o mesmo pavor do Anticristo despontando na derrocada universal da vida. O fim do mundo próximo... (CUNHA, 200I, p. 276)

O ascetismo exigido dos adeptos de um e outro movimento tinha a mesma justificativa: "todas as fortunas estavam a pique da catástrofe iminente e fora temeridade inútil conserválas" (CUNHA, 200I, p. 276).

Aqui se chega ao ponto fundamental: Euclides vê em Belo Monte as mesmas expectativas escatológicas cultivadas no seio do montanismo, a "última recrudescência do milenarismo e do profetismo" (RENAN, I929, p. 207). Essa identificação permite a Euclides mais uma vez recorrer a historiador francês, agora de forma servil. Se o profetismo de Montano, que, "como todos os profetas da nova aliança, transbordava de maldições contra o século e contra o império romano", não tratava de outra coisa que "o julgamento próximo, a punição dos perseguidores, a destruição do mundo profano, o reino de mil anos e suas delícias" (RENAN, I929, p. 215), a proclamação do Conselheiro não fugia ao modelo: tinha "o mesmo tom com que despontou na Frígia, avançando para o Ocidente. Anunciava, idêntico, o juízo de Deus, a desgraça dos poderosos, o esmagamento do mundo profano, o reino de mil anos e suas delícias" (CUNHA, 200I, p. 278). A identificação entre um movimento e outro fica reforçada pela transcrição. Com um agravante: a manifestação sertaneja tem séculos de atraso.

Muito provavelmente Euclides se viu autorizado a buscar revivescências destes cristianismos - para ele bizarros - no sertão do Belo Monte liderado pelo Conselheiro partindo de indicações do próprio Renan, que ele terá considerado sugestivas. Para o francês, os caminhos adotados pela ortodoxia eclesiástica não levaram ao desaparecimento daquelas expressões vetustas às quais esta se contrapunha: "o Corão e o islamismo não são outra coisa que prolongamento desta velha forma de cristianismo. [...] Por outro lado, em pleno século XIX, 
as seitas comunistas e apocalípticas da América fazem do milenarismo e do juízo final próximo a base de sua crença, como nos primeiros dias da primeira geração cristã" (RENAN, I929, p. 508; o destaque é meu). O Belo Monte passará a caber, a partir da invenção euclidiana, nesta perspectiva.

O termo "milenarismo" vem de uma passagem do livro do Apocalipse (20,I-6), e diz respeito à "crença num reino terrestre vindouro de Cristo e de seus eleitos - reino este que deve durar mil anos, entendidos seja literalmente, seja simbolicamente"; trata-se de uma "espera de um reino deste mundo, reino que seria uma espécie de paraíso terrestre reencontrado" (DELUMEAU, I997, p. I7; veja também VASCONCELLOS, I999, p. 79-92). Também chamado de quiliasmo, refere-se "à busca de uma salvação total, iminente, derradeira, terrena e coletiva" por "movimentos sociais que procuram uma mudança radical e maciça de acordo com um plano divino predeterminado. Seus membros rejeitam, em geral, a ordem social vigente e dela se afastam" (LEVINE, 1995, p. 29), pois

agora mesmo o mundo estava se aproximando, por meio de incessantes conflitos, de um estado sem nenhum conflito. Chegaria um momento em que, em uma prodigiosa batalha final, o deus supremo e seus aliados derrotariam as forças do caos e seus aliados humanos, aniquilando-os de uma vez por todas. A partir de então, a ordem divinamente estabelecida estaria presente de maneira absoluta; as necessidades e as misérias físicas seriam desconhecidas... a ordem do mundo jamais voltaria a ser perturbada ou ameaçada (COHN, I996, p. 296).

Assim, o milenarismo indica a "espera de um reino deste mundo, reino que seria uma espécie de paraíso terrestre reencontrado". No âmbito da tradição cristã, diz respeito à "crença num reino terrestre vindouro de Cristo e de seus eleitos - reino este que deve durar mil anos, entendidos seja literalmente, seja simbolicamente" (DELUMEAU, 1997, p. I8). A ação divina transformará o cosmos e o recriará de forma a se superarem os dramas presentes, o que modifica a postura diante da opressiva hora atual. $\mathrm{O}$ tempo novo integra um plano divino previamente estabelecido e de cuja revelação e conhecimento vivem os milenaristas, pois representará a salvação deles e a destruição dos pecadores, os responsáveis pelo atual estado de coisas (LANTERNARI, I994, p. 303-324).

A ser entendido desta forma, Belo Monte seria uma comunidade de pessoas ansiando pela vinda do milênio, de uma nova era, como tantas outras "pré-Jerusaléns, salas de espera 
espirituais onde se aguardava a entrada triunfal 'na mais fértil das terras', no reino miraculoso cheio de bênçãos para o corpo e para a alma" (LEVINE, I995, p. 33I-332; a expressão citada é de Cohn). O que ali se vivia era apenas prefiguração do que estava para se dar, do qual apenas os eleitos, os habitantes do arraial, seriam os beneficiados. Daí a separação do mundo, a recusa em observar as leis estabelecidas, a revolta contra a ordem política estabelecida.

O perfil do arraial conselheirista, tal qual desenhado em Os sertões, é decorrente desta perspectiva. Mas é preciso ser incisivo: Euclides funda essa vertente interpretativa a respeito de Belo Monte, que tanta repercussão haveria de ter posteriormente. E não teme tirar as consequências de sua invenção: entende-se, a partir daí, que os habitantes de Belo Monte "nada queriam desta vida", vivendo que estavam "sob a preocupação doentia da outra vida" (CUNHA, 200I, p. 299), embalados no delírio religioso que a todo momento seu líder alimentava em inflamadas pregações e com o testemunho de sua vida penitente. Assim, o diagnóstico é preciso: o Conselheiro é um herege. E se na antiga Frígia "uma credulidade desenfreada, uma fé a toda prova nos carismas espirituais, faziam do montanismo um dos tipos de fanatismo mais exagerados da história da humanidade” (RENAN, 1929, p. 233), no sertão baiano o que se assistia não merecia classificação menos taxativa: no "misticismo feroz e extravagante" do líder daquela agitação se condensavam "todas as crenças ingênuas, do fetichismo bárbaro às aberrações católicas, todas as tendências impulsivas das raças inferiores, livremente exercitadas na indisciplina da vida sertaneja” (CUNHA, 200I, p. 252).

\section{Buscando lá o que falta aqui}

Como se viu, o recurso a Renan, particularmente a sua exposição sobre o montanismo, ocupa papel significativo na tarefa hermenêutica a que Euclides se propõe: descobrir o sentido daquela manifestação sem sentido e atávica que foi o arraial liderado por Antônio Conselheiro. Salientei que a recuperação de manifestações heréticas do princípio do cristianismo objetivava também mostrar o atraso do que se via nos sertões baianos: "todas as seitas em que se fracionava a religião nascente, com os seus doutores histéricos e exegeses hiperbólicas, forneceriam hoje casos repugnantes de insânia. E foram normais" (CUNHA, 200I, p. 255). Antônio Conselheiro e seu séquito teriam lugar garantido e fariam sentido se houvessem aparecido dezessete, dezoito séculos antes. 
Mas vimos que a recuperação do montanismo ocupa lugar especial. E ao atavismo aqui se apresenta outra razão: o conselheirismo se alimentava de esperanças escatológicas similares, de cunho milenarista, àquelas de que viveram as comunidades cristãs da Frígia e de outras regiões nos séculos II e III.

No entanto, o que Euclides fez não foi colocar dois movimentos milenaristas em paralelo, mas transformar a pregação de Antônio Conselheiro, por meio de sua associação com a de Montano, em algo de cunho milenarista. A exposição de Renan forneceu a Euclides o quadro geral em que os poucos dados recolhidos em Belo Monte puderam caracterizar uma certeza: ele estava diante de um arraial quiliasta.

Mas esse perfil desenhado por Euclides não encontra apoio suficiente nos documentos conhecidos, mesmo aqueles transcritos em sua Caderneta de campo (I975), muito menos nos registros de outros jornalistas, militares e religiosos que conheceram o arraial e deixaram escritas suas impressões. A famosa "profecia", da qual Euclides transcreveu pequeno fragmento em Os sertões (CUNHA, 200I, p. 277), e na qual baseou sua avaliação, não permite concluí-lo. A parte principal do texto é a seguinte:

... Em I889 será despedido o Imperador da Corte pelos homens desgraçados do Brasil. Em I89I guerra; Nação contra Nação. Em I892 grande multidão de pecadores, uns convertidos e outros emendados que não se conhecerá nem rico nem pobre. Em I893, prata, ouro, cobre não haverá, correrá uns bilhetes vermelho feitos por mão dos homens, arrebentando da Tesouraria. Em I894 há de vir rebanhos mil correndo do centro da Praia para o certão então o certão virará praia e a praia virará certão. Em I895 os homens dos seus barcões abrirão as portas e assentar-se-ão em cima de seus barcões e não há de vender cinco réis de fazenda. Em I896 há de haver guerra Nação com a mesma Nação, o sangue há de correr na terra. Em I897 haverá muito pasto e pouco rasto e um só pastor e um só rebanho. Em I898 haverá m chapéus e poucas cabeças. Em I899 converter-se as águas em sangue o planeta há de aparecer no nascente com o raio do Sol q o ramo se confrontará com a terra e a terra em algum lugar se confrontará com o Céu, ajuntará-se astronámos da terra se ajuntará com os mares; planetas do Céu há de brigarem com os astronámos da terra. Há de chover uma grande chuva de estrelas; cairá muitos meteoros na terra que daí será o fim do mundo. Em I9or se apagarão as luses. Deus disse no Evangelho - eu tenho um rebanho que amo fora deste aprisco e é preciso que 
se reúnam, porq. há um só Pastor em um só rebanho. Diz o Profeta Jeremias para I90 existe um só pastor geral e um só rebanho. Fim

Neste Arraial de Belo Monte aos 24 de Janeiro de I890 (CUNHA, 1975, 74-75).

Os problemas deste texto são muitos: a Caderneta de Euclides mostra que ele é anônimo, sem qualquer indicação de ter sido escrito pelo Conselheiro; por outro lado, guarda semelhanças com muitos outros que circulavam pelo Nordeste inteiro (HOORNAERT, I997, p. II9-I20). Além disso, apresenta-se como surgido em Belo Monte no ano de I890, quando se sabe que o arraial de Canudos recebeu o novo nome em junho de I893, quando o Conselheiro ali se instalou com sua gente.

No entanto, qualquer que seja a data, com certeza estamos diante de um dos melhores exemplos, e o testemunho mais eloquente da presença em Belo Monte, daquilo que já se chamou, apropriadamente, de "cultura do fim do mundo" (POMPA, I995, p. I64), associada com situações de seca, guerra e calamidade. Além disso, sabe-se que esses temores quanto ao fim eram alimentados nas missões e pregações do clero.

A profecia em questão apresenta predições relativas a diversos anos, desde I822. A partir de I892 elas se referem a anos seguidos até I899. Para o ano I90I se afirma o fim, quando se confirmará a existência de um só rebanho e um só pastor. Uma expressão aí atribuída ao profeta Jeremias, mas cuja referência bíblica mais imediata se encontra no Evangelho segundo João (IO,I6). De toda forma, o rebanho guiado pelo único pastor, tendo enfrentado a guerra (iniciada em I896) e a carestia (I897), poderá aguardar o fim, num cenário de mortes (I898) e cataclismos cósmicos (I899), descritos com imagens que evocam claramente o Apocalipse. Se algum elemento pode ser de difícil identificação, a expectativa de fundo é clara: "Até o dia do julgamento!” (BARROS, I995, p. 80).

Além disso, se o texto da "Profecia" parece expressar adequadamente os temores e esperanças de ao menos parcela da gente que habitava Belo Monte no contexto da guerra, certamente não permite vislumbrar as motivações que terão feito o arraial se constituir, em I893. Frei João Evangelista de Monte Marciano (I895, p. 5), ao visitar o arraial, em meados de maio de I895, ouviu que a razão de as pessoas venderem seus bens e irem viver junto ao Conselheiro era que à beira do rio Vaza-barris se encontrava "a terra da promissão, onde corre um rio de leite, e são de cuscuz de milho os barrancos". Outros testemunhos apontam em direção semelhante. E o relatório do missionário não aponta para nenhum aspecto que 
apontasse para esperanças apocalípticas ou milenaristas, o que é admirável em se tratando de um documento de alguém com conhecimentos ao menos básicos em termos de doutrina e teologia católica. O cenário da guerra é que trará à tona expectativas desse teor no interior do arraial.

Assim, a interpretação de Euclides ao material encontrado em Belo Monte é questionável, por não considerar uma distinção básica, entre expectativas milenaristas e aguardo de um juízo final, temerário e iminente; aquelas supõem este, mas nem todo julgamento escatológico é pensado na perspectiva de um milênio vindouro. ${ }^{2}$ São poucas as situações, como é o caso desta, em que se pode identificar com clareza a data do nascimento de um modelo e tradição interpretativos, no caso, a invenção euclidiana de um Belo Monte milenarista, que se mostraria tão eficaz nas décadas seguintes, até hoje.

Este caráter milenarista, como se pode ver, Euclides vai buscar em Montano. Nos documentos havia indícios da expectativa de um julgamento final, a ocorrer, segundo a profecia mencionada, na virada do século XIX para o XX. Mais nada. A expectativa pela já mencionada "salvação total, iminente, derradeira, terrena e coletiva" não pode ser deduzida dos materiais coletados e registrados na Caderneta de campo de Euclides.

A ignorância a respeito das convicções conselheiristas, mormente as de cunho escatológico, talvez explique as razões que levaram o autor, no esforço em compreendê-las, a recorrer a Montano. Mas não era necessário ir tão longe. Bastava transcrever em sua obra maior um diálogo esclarecedor que travou com um "jaguncinho" de I4 anos, a I9 de agosto de I897, registrado numa de suas reportagens enviadas ao Estado de São Paulo. Aprisionado e trazido à capital Salvador, Agostinho é submetido a interrogatório que mais parece espaço para satisfação de curiosidades. Mas Euclides tem consciência da importância do momento. Depois de ter-se informado sobre a gente do arraial e seus líderes, sobre o cotidiano da vila, levantou, junto com outros militares, interrogações "sobre questões mais sérias": armas, e convicções religiosas. Quanto a estas últimas, a surpresa de Euclides se manifesta na resposta à pergunta pela promessa feita pelo Conselheiro a quem morresse na luta: "Salvar a alma" (CUNHA, 2000, p. III).

Por que a resposta "soou inesperada" a Euclides, se "salvar a alma" era tudo a que o cristão mediano, minimamente conhecedor da doutrina católica convencional, aspirava? O

\footnotetext{
${ }^{2}$ Não é incomum que esta confusão ocorra entre os analistas e intérpretes de fenômenos sociorreligiosos, constata Delumeau (I996, p. 207-215).
} 
espanto vem justamente da concordância entre as promessas do herege fanático e ignorante e o que os padres ensinavam conforme o catecismo tridentino, certamente conhecido de Euclides! Pois para o inquiridor, que neste momento sintetizava o sentimento da nação e perguntava o que esta na verdade julgava já saber, importava marcar a diferença, arrancar a aberração, comprovar o absurdo. A concordância então espanta, incomoda, e começa a colocar em cheque a polarização entre doutrinas palatáveis e fanatismo, entre religiosidade viável e manifestações derivadas da ignorância. Euclides não terá notado, ou pelo menos não registrou (tê-lo-á compreendido depois?) que a diferenciação entre a experiência religiosa em Belo Monte e aquela institucionalizada no cristianismo católico de seu tempo se encontra em outras latitudes. De toda forma, não podia contar com tal concordância em assunto sobre o qual julgava ter certeza e que justificava todos os adjetivos com que os rudes sertanejos eram classificados: aquilo em que acreditavam. Não podia crer que não cressem em milagres ou ressurreições retumbantes. $\mathrm{O}$ fato de esta parte do interrogatório e as surpresas por ele provocadas não terem sido inseridas em Os sertões, certamente porque não se coadunavam com o modelo de Belo Monte que o autor insiste em alimentar, esclarece, por outro lado, porque foi necessário recorrer ao montanismo e a Renan: para configurar um modelo claramente distinto, em que a diferença fica definitivamente marcada, o atavismo salientado, a aberração estabelecida. Também nesse sentido é verdade que Euclides, na confecção de $O s$ sertões, "tem necessidade de interpretar o movimento de Canudos como movimento milenarista" (DECCA, 2002, p. I64; o destaque é meu): se a presença in loco o convenceu, a custo, de que o modelo colhido em Victor Hugo, o da Vendeia francesa, não era viável para interpretar a saga de Belo Monte’ , será preciso outro, que confirme a insensatez do projeto do Conselheiro.

Uma última observação. A leitura apressada que Euclides fez de Renan e os vínculos que atabalhoadamente estabeleceu entre os movimentos religiosos do início do cristianismo e a vivência religiosa do Conselheiro e sua gente foram responsáveis por pelo menos mais um equívoco, disfarçado sob a retórica impecável de sempre. Trata-se da conhecida expressão "gnóstico bronco" aplicada ao Conselheiro, após a inserção dele no rol dos líderes cristãos

\footnotetext{
${ }^{3}$ Como é sabido, Vendeia é uma região do oeste da França em cujo interior se articulou reação aos rumos vividos pelo país a partir do processo revolucionário de $\mathrm{I789}$, sob a égide da recuperação dos valores e práticas associados ao Ancien Régime. Euclides, antes de seguir para o palco da guerra contra o Belo Monte, escrevera dois artigos para o jornal O Estado de São Paulo, em que qualificava o vilarejo conselheirista como "a nossa Vendeia". E mesmo depois de ter constatado, in loco, que não procediam os boatos que tomavam o arraial como foco de uma conspiração restauradora do império brasileiro, pretendeu dar ao livro que haveria de escrever sobre o tema o mesmo título de seus artigos anteriores (ABREU, I998, p. 165; MOREIRA, 2009, p.I73-I74).
} 
heréticos do século II (CUNHA, 200I, p. 255). O montanismo, com suas esperanças e certezas apocalípticas, caracterizava uma tendência religiosa que andava na contramão do gnosticismo, centrado numa espiritualidade com viés intimista e especulativo e pouca (ou nenhuma) preocupação escatológica, no sentido mais comum que este termo costuma assumir. Se "o gnosticismo teve um papel considerável na obra da propaganda cristã", ao ter sido "frequentemente a transição pela qual se passava do paganismo ao cristianismo" (RENAN, I929, p. 139), e Euclides o reconheceu (200I, p. 254), acrescentando que tal transição foi obrigatória (NASCIMENTO, I997, p. I7-I8), não cabe atribuir ao autor francês a responsabilidade pela inserção do montanismo no rol das expressões gnósticas do século II. Não é possível vincular Antônio Conselheiro ao mesmo tempo ao montanismo e ao gnosticismo. Essa contradição não terá sido percebida devido à pouca atenção dada a detalhes trazidos pelas fontes utilizadas por Euclides, particularmente daquela que lhe configurou o panorama religioso dos inícios cristãos, e que tanta serventia lhe teve.

\section{Implicações}

“Quem não vê o enorme perigo de uma crença como essa?", eis a pergunta de Renan para expor e justificar a reação da hierarquia eclesiástica ao montanismo que se espalhava ameaçadoramente por toda parte (I929, p. 2I2-2I3). Euclides a todo momento, ao apresentar Antônio Conselheiro e sua suposta pregação, se pergunta pelo perigo, mas também pela insânia das concepções que faziam a vida e as ilusões da gente de Belo Monte. Para ambos a solução era um só: "Se Marco Aurélio... tivesse empregado a escola primária e um ensino de Estado racionalista, ele teria prevenido mais eficazmente a sedução do mundo pelo sobrenatural cristão" (RENAN, I929, p. 345-346). Com certeza, "é impossível não pensar aqui no mestre-escola reivindicado [por Euclides] para os sertões nordestinos" (SILVA e SILVA, I986). Cá e lá a educação, meio para eliminar atavismos, para fazer abandonarem-se crendices religiosas e fantasmagóricas.

E não nos perguntemos por quais razões em Os sertões Euclides omite, também nessa oportunidade, informação que anteriormente recolhera e registrara, dando conta da existência de escolas em Belo Monte (CUNHA, 1975, p. 23)... De toda forma esse detalhe patenteia o incômodo do escritor perante "um levante cujo fulcro agregador é a religião, coisa que, francamente, para ele cheirava à pior das superstições" (GALVÃO, I98I, p. 94). 
Mas o percurso feito aqui terá mostrado que os problemas da leitura euclidiana vão mais longe, e mostra que Antônio Conselheiro e sua gente "não entregaram a chave de sua decifração aos métodos utilizados pelo escritor" (GALVÃO, I98I, p. 95). Se foi no mínimo infeliz a interpretação da experiência religiosa vivida em Belo Monte tendo por base os escritos de Renan e, em particular, o montanismo aí aparecido, não se pode deixar de perceber a conveniência dela para os propósitos do escritor: "a comparação [entre Montano e Antônio Conselheiro] é precipitada e distorce os fatos históricos, mas vai ao encontro do resultado que proveio da [sua] teoria da mestiçagem e da coletividade anormal” (OTTEN, I990, p. 27). O vínculo entre o frígio e o bronco joga papel importante no esforço euclidiano de ao mesmo tempo tomar partido da gente conselheirista contra o massacre a ela perpetrado e manifestar a total inviabilidade do arraial sertanejo. Não tinha razão de ser uma comunidade que vivia em função de expectativas tão disparatadas e sem sentido.

Além disso, e a despeito da tonalidade cientificista do argumento euclidiano, vale notar a sintonia entre ele e as preocupações das elites eclesiásticas que, no decorrer dos séculos, esmeraram-se em desqualificar as manifestações religiosas autônomas, dos indígenas e das comunidades negras, e mais recentemente as próprias expressões populares do catolicismo. Só nessa perspectiva, de longa duração na história brasileira, se entendem expressões, estranhas na pena de um agnóstico, como aquela segundo a qual Belo Monte encarnava o caso de uma "seita esdrúxula - caso de simbiose moral em que o belo ideal cristão surgia monstruoso dentre aberrações fetichistas" (CUNHA, 200I, p. 302). Como poderia o escritor, de outra forma, afirmar que o Conselheiro "abeirara-se apenas do catolicismo mal compreendido" (CUNHA, 200I, p. 279)? Por que qualificar o "beija das imagens" como "transmutação do cristianismo incompreendido" (CUNHA, 200I, p. 314)?

\section{Conclusão}

Euclides da Cunha não conheceu as prédicas de Antônio Conselheiro. Sua afirmação de que nelas se expressaria "uma oratória bárbara e arrepiadora" (CUNHA, 200I, p. 274) é gratuita, e forma parte do quadro cujas características básicas procurei aqui expor. Sabe-se que um dos cadernos atribuídos ao Conselheiro passou por suas mãos, mas anos após o lançamento de Os sertões, dias antes de sua morte trágica (NOGUEIRA, I997, p. 35-36). Se tivesse tido a oportunidade de folhear as páginas do caderno, certamente se espantaria com a 
distância entre o quadro que desenhou e aquilo que agora lhe vinha ao conhecimento: um pensamento religioso coerentemente articulado. E o livro teria de ser reescrito...

Como tal não ocorreu, e o caderno precisou esperar até I974 para ser editado e conhecido, o modelo euclidiano fez escola. Mesmo que Montano não fosse de novo citado, a tese de um Belo Monte milenarista seduziu estudiosos díspares (QUEIROZ, I997, p. 215-24I; LEVINE, I995) e configurou as referências comumente atribuídas ao arraial. Se tantos aspectos da interpretação euclidiana sobre o Belo Monte de Antônio Conselheiro já foram percebidos como frutos muito mais dos títulos de que dispunha (e de como as lia, obviamente) que dos dados que ele pôde recolher do sertão, também o de um Belo Monte milenarista parece merecer o mesmo diagnóstico. O que, se não impede a apaixonada defesa que Euclides faz da gente sertaneja e a eloquente denúncia do brutal massacre a ela perpetrado, limita o alcance delas, já que, no fim das contas, o empreendimento conselheirista, com bases assim tão frágeis e ultrapassadas, era inviável. E, na medida em que é do Conselheiro que brota o discurso quiliasta de tamanha capacidade de aglutinação, não estranhará que seja sobre ele, ao final, que recaia a responsabilidade praticamente única pela tragédia ocorrida nos sertões. É esse o sentido do capítulo IV de "O homem" em Os sertões, o capítulo nuclear do livro, garantia de sua coerência estrutural, para além e para baixo das tensões que alguns críticos quiseram ver na obra, oscilando entre explicação e denúncia do massacre.

\section{Bibliografia}

ABREU, Regina. O enigma de Os sertões. Rio de Janeiro: Funarte/Rocco, 1998.

ANDRADE, Olímpio de Souza. História e interpretação de Os sertões. 4 ed., Rio de Janeiro: Academia Brasileira de Letras, 2002.

BARROS, Luitgarde. Crença e parentesco na guerra de Canudos. In: MENEZES, Eduardo B. Diatahy de e ARRUDA, João. Canudos: as falas e os olhares. Fortaleza: Editora da Universidade Federal do Ceará, I995, p. 74-89.

CHAUÍ, Marilena. Brasil: mito fundador e sociedade autoritária. São Paulo: Fundação Perseu Abramo, 2000.

COHN, Norman. Caos, cosmos e o mundo que virá. A origem das crenças no Apocalipse. São Paulo: Companhia das Letras, 1996. 
COUTO, Manoel José Gonçalves. Missão abreviada para despertar os descuidados, converter os pecadores e sustentar o fruto das missões. 9 ed., Porto: Casa de Sebastião José Pereira, I873.

CUNHA, Euclides da. Caderneta de campo. São Paulo: Cultrix, 1975.

CUNHA, Euclides. Diário de uma expedição. São Paulo: Companhia das Letras, 2000.

CUNHA, Euclides da. Os sertões: campanha de Canudos. São Paulo: Ateliê / Imprensa Oficial do Estado, 200I.

DECCA, Edgar Salvadori de. Euclides e Os sertões: entre a literatura e a história. In: FERNANDES, Rinaldo de (org.) O clarim e a oração. São Paulo: Geração, 2002, p. I57-I88.

DELUMEAU, Jean. História do medo no Ocidente: I30o-I8oo. São Paulo: Companhia das Letras, 1996.

DELUMEAU, Jean. Mil anos de felicidade: uma história do paraíso. São Paulo: Companhia das Letras, 1997 .

GALVÃO, Walnice Nogueira. Gatos de outro saco: ensaios críticos. São Paulo, Brasiliense, I98I.

GUERRA, Sérgio. Universos em confronto: Canudos x Bello Monte. Salvador, Uneb, 2000.

HOORNAERT, Eduardo. Os anjos de Canudos: uma revisão histórica. Petrópolis: Vozes, 1997.

LANTERNARI, Vittorio. Milênio. In: Enciclopédia Einaudi. Lisboa: Imprensa Nacional - Casa da Moeda, I994, v.30, p. 303-324.

LEVINE, Robert. O sertão prometido: o massacre de Canudos. São Paulo: Edusp, 1995.

LIMA, Luiz Costa. Terra ignota: a construção de Os sertões. Rio de Janeiro: Civilização Brasileira, I997.

MARCIANO, João Evangelista de Monte. Relatório apresentado, em I895, pelo reverendo Frei João Evangelista de Monte Marciano, ao Arcebispado da Bahia, sobre Antonio Conselheiro e seu séquito no arraial dos Canudos. Salvador: Correio da Bahia, I895 (edição em fac-símile pelo Centro de Estudos Baianos, 1987).

MOREIRA, Raimundo Nonato Pereira. E Canudos era a Vendeia: o imaginário da Revolução Francesa na construção da narrativa de Os sertões. São Paulo: Annablume, 2009.

NASCIMENTO, José Leonardo do. De Marc-Aurèle de Ernest Renan a Os sertões de Euclides da Cunha: milenarismo e atraso histórico. In: Interpretações sobre o movimento sertanejo de Canudos. Lorena: Faculdades Salesianas, I997, p. I3-I8.

NOGUEIRA, Ataliba. António Conselheiro e Canudos: revisão histórica. 3 ed., São Paulo: Atlas, I997. 
OTTEN, Alexandre. "Só Deus é grande". A mensagem religiosa de Antônio Conselheiro. São Paulo: Loyola, I990.

POMPA, Maria Cristina. Memórias do fim do mundo: para uma leitura do movimento sociorreligioso de Pau de Colher. Mestrado em Antropologia, UNICAMP, Campinas, 1995.

QUEIROZ, Maria Isaura Pereira de. O messianismo no Brasil e no mundo. 2 ed., São Paulo: AlfaÔmega, 1977 .

RENAN, Ernest. Marc-Aurèle et la fin du monde antique. 26 ed., Paris: Calmann-Lévi, 1929.

SILVA, Célia Mariana F. F. da e SILVA, Manoel Roberto F. da. Alexandre de Abonótico. In: Gazeta do Rio Pardo (Suplemento Euclidiano). São José do Rio Pardo, agosto de 1986.

VASCONCELLOS, Pedro Lima. A vitória da vida: milênio e reinado em Apocalipse 20,I-Io. Revista de Interpretação Bíblica Latino-Americana, n.34, 1999, p. 79-92.

VASCONCELLOS, Pedro Lima. O Belo Monte de Antonio Conselheiro: uma invenção "biblada". Maceió: Edufal, 2015.

VENTURA, Roberto. Canudos como cidade iletrada: Euclides da Cunha na urbs monstruosa. Revista de Antropologia, v.40, n.I, p. I65-I8I. 